\title{
ALPHA-DECAY RADIATION DAMAGE STUDY OF A GLASS-BONDED SODALITE CERAMIC WASTE FORM
}

\author{
S. M. Frank, T. L. Barber, T. DiSanto, K. M. Goff, S. G. Johnson, J-F Jue, M. Noy, T. P. \\ O'Holleran and W. Sinkler* \\ Argonne National Laboratory-West, PO Box 2528, Idaho Falls, ID, 83403-2528 \\ *Current Address: UOP, Des Plaines, IL 60017
}

\begin{abstract}
Effects of alpha decay on the ceramic waste form used to immobilize fission products and actinides accumulated from electrometallurgical treatment of Department of Energy metallic spent nuclear fuel is being studied. This involved the preparation of a surrogate ceramic waste form containing two-weight percent plutonium-238 and monitoring changes to the waste form resulting from alpha-decay damage. The phase assembly of the ceramic waste form consists of glass-bonded sodalite with small quantities of nepheline, halite and plutonium oxide. The waste form has been monitored for three years and has acquired an internal alpha-decay dose of $1 \times 10^{18}$ disintegrations per gram of material. Methods used to monitor the material include: density determination to measure possible macroscopic swelling, chemical durability measured by leach testing, microstructure analysis by scanning and transmission electron microscopy and phase composition by powder x-ray diffraction. The investigation has, to date, found little alteration to the waste form due to alpha-decay damage. X-ray diffraction analysis has detected a unit cell volume increase of 0.7 percent of the plutonium oxide phase. Furthermore, bubbles and/or voids have been observed by transmission electron microscopy in the sodalite and glass phase. The origin of these defects is unclear and under investigation.
\end{abstract}

\section{INTRODUCTION}

Electrometallurgical treatment of spent, metallic nuclear fuel, at Argonne National Laboratory in Idaho, produces a relatively pure uranium product and two high-level waste forms [1]. These extremely durable waste forms are termed the metallic and ceramic waste forms [2]. The ceramic waste form (CWF) contains alkali, alkaline earth, rare earth and halide fission products and small quantities of uranium and transuranics elements ( $<1$ weight percent). To investigate the effects of alpha decay on the CWF, surrogate waste form material was produced containing approximately 2 weight percent plutonium-238. The high specific activity of ${ }^{238} \mathrm{Pu}$ 'accelerates' the damage to the host material such that the current ${ }^{238} \mathrm{Pu}$ alpha-decay dose of $1 \mathrm{x}$ $10^{18}$ alpha-decays/gram of material, obtained after 3 years, corresponds to an equivalent ${ }^{239} \mathrm{Pu}$ decay exposure time of 1000 years. Incorporation of high-activity radionuclides is but one method applied to the study of radiation damage to materials. Please see Ewing et al. [3] for a review on this topic.

This multiyear study of alpha-decay damage involves periodic measurement of the ${ }^{238} \mathrm{Pu}-$ loaded CWF to determine changes to the materials chemical durability, physical characteristics and microstructure [4,5]. The testing includes chemical durability determined by the product consistency test (PCT), macroscopic volume changes measured by density analysis, phase composition and individual phase volume change measured by x-ray diffraction (XRD), and microscopic analysis of the waste form to monitor alteration to the microstructure and elemental composition by both scanning electron microscopy (SEM) and transmission electron microscopy (TEM). This paper describes the most current measurements and comparison to previous analyses of the ${ }^{238} \mathrm{Pu}$-loaded CWF. 


\section{SAMPLE PREPARATION}

The material used for this study was produced by first oxidizing metallic ${ }^{238} \mathrm{Pu}$ to $\mathrm{PuCl}_{3}$ in $\mathrm{LiCl} / \mathrm{KCl}$ eutectic salt that also contained small quantities of surrogate fission products. The

${ }^{238} \mathrm{Pu}$ containing eutectic salt was then hot mixed with dried zeolite 4A. This mixing step occludes the salt into the zeolite matrix. After contacting with the zeolite, the $\mathrm{PuCb}_{3}$ converts to the oxide. This conversion is presumably due to the reaction of $\mathrm{Pu}$ with oxygen from residual water in the zeolite. The salt-occluded zeolite was mixed with a glass binder in a ratio of 3:1 zeolite to glass. This material was then consolidated using a hot uniaxial press at a temperature of $1023 \mathrm{~K}$ and a pressure of $34 \mathrm{MPa}$. During processing, the zeolite is transformed to sodalite. The ${ }^{238} \mathrm{Pu}$ loading in the final material was approximately $2 \mathrm{wt} \%$. This quantity of $\mathrm{Pu}$ is roughly 3 to 15 times the actual concentration of $\mathrm{Pu}$ found in the CWF produced during the fuel treatment process. Recent analysis of the ${ }^{238} \mathrm{Pu} /{ }^{239} \mathrm{Pu}$ ratio of the plutonium used to in this study indicates a slightly smaller quantity of ${ }^{238} \mathrm{Pu}$ than originally thought. This decrease in the quantity of ${ }^{238} \mathrm{Pu}$ and its corresponding dose rate have been corrected here and are different than those reported earlier in ref. 4 and 5.

\section{MICROSTRUCTURE}

Scanning electron microscopy is performed using a Zeiss DSM 960A microscope equipped with secondary and backscatter electron detectors as well as energy-dispersive and wavelengthdispersive (EDS and WDS, respectively) x-ray detectors. TEM is performed using a JEOL 2010 transmission electron microscope equipped with an EDS detector.

The microstructure of the ${ }^{238} \mathrm{Pu}$-loaded CWF is very similar to the reference (non-Pu loaded) CWF and consists of 5 to 20-micron diameter sodalite regions surrounded by the glass binder. Plutonium is found primarily as $\mathrm{PuO}_{2}$ in the glass areas between sodalite regions. A second $\mathrm{Pu}$ containing phase has been identified by TEM [4] as a tetragonal aluminosilicate phase, and a strongly faceted, needle-like phase containing Pu has also been observed. Neither of these last two $\mathrm{Pu}$ containing phases have been observed in the actual CWF that contains approximately $0.1 \mathrm{wt} \% \mathrm{Pu}$ and their presence is possibly due to the greater Pu loading used in this study. Periodic analysis of the ${ }^{238} \mathrm{Pu}$-loaded CWF by SEM indicates no variation to the microstructure or elemental distribution of phases in the waste form after 3 years exposure, or a cumulative dose of $9 \times 10^{17}$ alpha decays/g as shown in Figure 1.

TEM analysis of the waste form has observed either bubbles and/or voids in both the sodalite and glass phases as shown in Figures $2 \mathrm{a}$ and $2 \mathrm{~b}$. The origin of these defects is unclear at this time, but could be caused by a number of events. Possible causes of the bubble/void formation include: an artifact from material processing, an artifact from electron bombardment during analysis, voids formed from recoil nuclei after alpha decay, bubble formation from radiolytic gas products $\left(\mathrm{H}_{2} \mathrm{O}, \mathrm{O}_{2}, \mathrm{Cl}_{2}\right.$, etc. $)$ [6-10], or from $\mathrm{He}$ accumulation due to alpha decay [11-13]. It is extremely difficult to determine the exact cause of microstructural features such as the bubbles and /or voids shown in Figure 2. However, there is indication, as observed by TEM analysis, that these features may also be present in CWF specimens that do not contain $\mathrm{Pu}$, and in the ${ }^{238} \mathrm{Pu}$-loaded CWF analyzed shortly after it was produced and thus at very low alpha-decay exposure. Elemental x-ray analysis of the bubble/void regions by EDS does not help in elucidating an explanation of these features, except that EDS does not detect the presence of Ar that can be introduced during sample preparation. Unfortunately, He can not be measured by EDS analysis due to He x-ray absorption by the beryllium window of the analyzer. Also, due to significant local concentrations of oxygen and chlorine in the matrix material, identification of these radiolytic gas products is not possible. It does appear, however, that sufficient structural 
defects are introduced into the CWF during processing that provide readily available sinks and diffusion pathways to allow for the accumulation of gas generation from radiolytic processes. Of particular interest is the observation that no microcrack formation or phase debonding from the matrix material is occurring after three years of alpha-decay damage. This is significant in that these material defects caused by alpha decay damage are what typically cause the greatest degradation to the waste form after prolonged exposure to radiation decay.
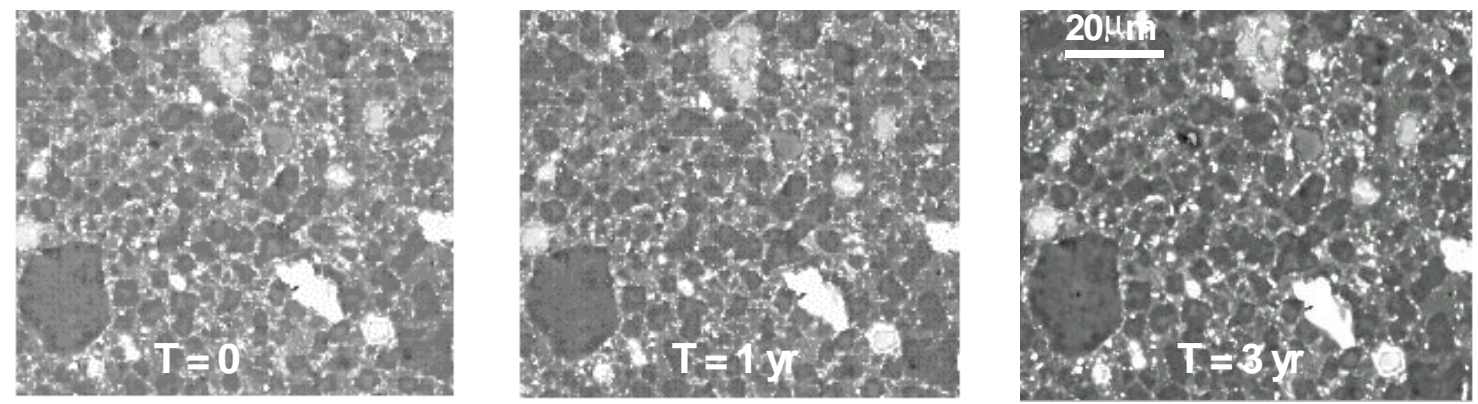

Figure 1. SEM anaylsis of selected region of the ${ }^{238} \mathrm{Pu}$-loaded CWF sample after 3 years or 9 $\mathrm{x} 10^{17}$ alpha decays/g cumulated dose. No change to the sample is observed. The micrograph shows sodalite as dark areas, glass as gray areas and $\mathrm{PuO}_{2}$ as the white regions.
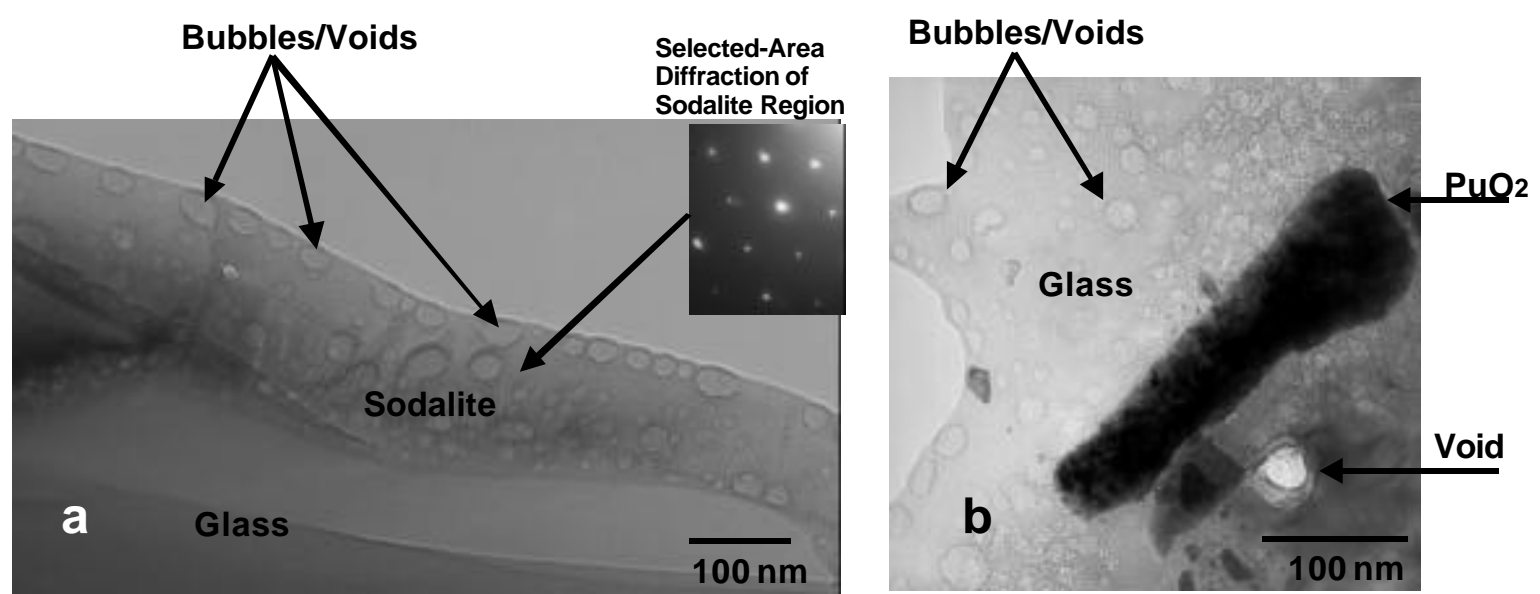

Figure 2. TEM image showing bubbles/voids within the sodalite (a) and glass phases (b) of the ${ }^{238} \mathrm{Pu}$-Loaded CWF. How these bubbles/voids are formed is unclear at this time, but may be related to bubble formation from alpha decay, or as an artifact from sample production. The feature labeled void in figure $1 \mathrm{~b}$ was most likely previously occupied by a $\mathrm{NaCl}$ crystal. There is no indication of microcrack formation or debonding of phases due to alpha decay.

\section{CHEMICAL DURABILITY}

Chemical durability of the ${ }^{238} \mathrm{Pu}$-loaded CWF is monitored using the PCT leaching method (ASTM method 1285) [14]. This test involves grinding the material to a specific particle size range, washing the powder, loading weighed quantities of the powder into stainless steel test vessels and adding known volumes of demineralized water (DM) leachant to the vessels. The volume of leachant added resulted in a ratio of sample surface area to leachant volume of $2000 \mathrm{~m}^{-1}$. Glass approved reference materials (ARM), used as a check standard, and blank solutions were also added to test vessels. The sealed vessels were then placed in an oven at $90^{\circ}$ $\mathrm{C}$ for seven days. At the end of the test, the leachate was filtered and collected. Each vessel was 
then washed with DM water, a 2 volume percent nitric acid solution was added to each vessel and placed in the oven at $90^{\circ} \mathrm{C}$ for 18 hours. This additional step is performed to remove any adsorbed material from the vessel walls. Finally, the original PCT powder water wash, filtered leachate solutions and acid strip solutions were analyzed by either inductively coupled plasmamass spectrometry, or inductively coupled plasma-atomic emission spectroscopy for leached elemental CWF constituents. The PCT results from the initial test on the ${ }^{238} \mathrm{Pu}$-loaded CWF and the second year PCT after $6 \times 10^{17}$ alpha-decays/g are shown in Table I.

The overall elemental release behavior varies between the first and second ${ }^{238} \mathrm{Pu}$-loaded CWF PCT. For the major matrix and salt components released from the ${ }^{238} \mathrm{Pu}$-loaded waste form, only $\mathrm{Cl}, \mathrm{B}$ and $\mathrm{Pu}$ are released in statistically significant (release differences greater than $2 \sigma$ uncertainty) greater quantities during the second PCT than the initial test. For the release of minor constituents from the ${ }^{238} \mathrm{Pu}$ PCT, in which comparisons can be made (i.e. Nd and Cs), the releases during the second test is statistically greater than the initial PCT. Also note that the experimental uncertainties for measurements made during the first PCT are quite large. Better instrumental methods developed since the first test have substantially reduced the measurement uncertainties and the next ${ }^{238} \mathrm{Pu}$-loaded CWF PCT analysis will provide a clearer understanding if indeed the elemental release is increasing with increasing alpha-decay dose. Nonetheless, the elemental release, particularly for $\mathrm{Pu}$, is very low.

Table I. Normalized elemental release in $\mathrm{g} / \mathrm{m}^{2}$ from a 7-day PCT leachate solution of ${ }^{238} \mathrm{Pu}-$ loaded CWF for the first (cumulative dose $4 \times 10^{16}$ alpha-decays $/ \mathrm{g}$ ) and second (cumulative dose $6 \times 10^{17}$ alpha-decays $\left./ \mathrm{g}\right)$ test periods. The normalized release $\left(\mathrm{g} / \mathrm{m}^{2}\right)$ is the average value from triplicate tests \pm the measurement uncertainty in percent at the $1 \sigma$ confidence interval. The table is arranged in decreasing order of elemental abundance (in atom \%) in the waste form.

\begin{tabular}{|c|c|c|}
\hline $\begin{array}{c}\text { Major Waste Form } \\
\text { Constituents Released }\end{array}$ & $\begin{array}{c}\text { Normalized Release }\left(\mathrm{g} / \mathrm{m}^{2}\right) \text { from } \\
\text { First }{ }^{238} \mathrm{Pu} \text { CWF PCT } \\
\pm \text { Measurement Uncertainty }\end{array}$ & $\begin{array}{c}\text { Normalized Release }\left(\mathrm{g} / \mathrm{m}^{2}\right) \text { from } \\
\text { Second }{ }^{238} \text { Pu CWF PCT } \\
\pm \text { Measurement Uncertainty }\end{array}$ \\
\hline $\mathrm{Si}$ & $\mathrm{NA}$ & $0.0383 \pm 0.0019$ \\
\hline $\mathrm{Al}$ & $0.0350 \pm 0.0035$ & $0.0344 \pm 0.0017$ \\
\hline $\mathrm{Na}$ & $\mathrm{NA}$ & $0.231 \pm 0.012$ \\
\hline $\mathrm{Cl}$ & $0.376 \pm 0.038$ & $0.736 \pm 0.037$ \\
\hline $\mathrm{Li}$ & $0.439 \pm 0.044$ & $0.477 \pm 0.048$ \\
\hline $\mathrm{K}$ & $0.0897 \pm 0.072$ & $0.134 \pm 0.007$ \\
\hline $\mathrm{B}$ & $0.228 \pm 0.023$ & $0.352 \pm 0.018$ \\
\hline $\mathrm{Pu}$ & $0.000650 \pm 0.00016$ & $0.00198 \pm 0.0010$ \\
\hline $\mathrm{Nd}$ & $0.00123 \pm 0.00025$ & $0.00484 \pm 0.00097$ \\
\hline $\mathrm{Cs}$ & $0.148 \pm 0.015$ & $0.350 \pm 0.018$ \\
\hline $\mathrm{I}$ & $\mathrm{NA}$ & $0.207 \pm 0.052$ \\
\hline
\end{tabular}

\section{PHYSICAL CHARACTERISTICS}

Density Determination

Density measurements are performed periodically on the ${ }^{238} \mathrm{Pu}$-loaded CWF using an immersion technique. Decrease in density can be attributed to macroscopic swelling due to radiation damage to the bulk material [15]. The method involves first weighing the sample then measuring the buoyancy weight of the sample in water. The density of an aluminum standard, and a non-plutonium CWF check standard is measured along with the sample to determine the 
uncertainty of the measurements and as a calibration check. The measurements are performed in an air atmosphere glove box. The balance and immersion apparatus used is manufactured by OHAUS, model AP250D. The density measurements are given in Table II.

Table II. Cumulated alpha decay dose ( $\alpha$-decays $/ \mathrm{g})$ and density measurements $\left(\mathrm{g} / \mathrm{cm}^{3}\right)$ from ${ }^{238} \mathrm{Pu}$-loaded $\mathrm{CWF}$, and the densities of a non-Pu CWF check standard and aluminum standard.

\begin{tabular}{|c|c|c|c|}
\hline $\begin{array}{c}\text { Dose } \\
(\alpha \text {-decay/gram })\end{array}$ & $\begin{array}{c}{ }^{238} \text { Pu-Loaded CWF } \\
\text { Density }\left(\mathrm{g} / \mathrm{cm}^{3}\right)\end{array}$ & $\begin{array}{c}\text { CWF Check Standard } \\
\text { Density }\left(\mathrm{g} / \mathrm{cm}^{3}\right)\end{array}$ & $\begin{array}{c}\text { Aluminum Standard } \\
\text { Density }\left(\mathrm{g} / \mathrm{cm}^{3}\right)\end{array}$ \\
\hline $4.2 \mathrm{E} 16$ & 2.424 & NA & 2.690 \\
\hline $1.0 \mathrm{E} 17$ & 2.417 & NA & 2.700 \\
\hline $2.0 \mathrm{E} 17$ & 2.419 & NA & 2.694 \\
\hline $3.2 \mathrm{E} 17$ & 2.420 & NA & 2.692 \\
\hline $3.8 \mathrm{E} 17$ & 2.425 & $2.342 \pm 0.004$ & 2.699 \\
\hline $6.4 \mathrm{E} 17$ & 2.425 & 2.339 & 2.697 \\
\hline $7.3 \mathrm{E} 17$ & 2.426 & 2.346 & 2.694 \\
\hline $8.0 \mathrm{E} 17$ & 2.420 & 2.346 & 2.699 \\
\hline $9.0 \mathrm{E} 17$ & 2.434 & 2.334 & $2.695 \pm 0.004$ \\
\hline Average \pm Std. & $2.423 \pm 0.005$ & $2.342 \pm 0.005$ & $(0.13 \%)$ \\
Dev. $(\%$ RSD $)$ & $(0.21 \%)$ & $(0.21 \%)$ & \\
\hline
\end{tabular}

NA, not analyzed.

The density of the ${ }^{238} \mathrm{Pu}$-loaded CWF sample has remained unchanged, with respect to the measurement uncertainty, during the testing period to date. The density of the ${ }^{238} \mathrm{Pu}$-loaded CWF, as determined by immersion in water, is $2.42 \pm 0.01 \mathrm{~g} / \mathrm{cm}^{3}$. This density compares to an average density of $2.35 \pm 0.02 \mathrm{~g} / \mathrm{cm}^{3}$ for non-Pu reference CWF material. The higher density of the ${ }^{238} \mathrm{Pu}$-loaded CWF is attributed to the high $\mathrm{Pu}$ loading in the sample. A decrease in density of the sample provides the most direct evidence of macroscopic volume expansion due to alphadecay damage, yet as mentioned none has been observed at the dose level of $9 \times 10^{17}$ alphadecays/gram of material.

$\underline{\text { XRD Analysis }}$

A Scintag X1 diffractometer with $\mathrm{Cu}-\mathrm{K}_{\alpha}$ radiation is used for powder $\mathrm{XRD}$ analysis. The sample is maintained in a vacuum tight containment chamber with beryllium window. Approximately $2 \mathrm{wt} \%$ of the $\mathrm{LaB}_{6}$ NIST standard reference material (SRM) 660 was mixed with the powdered ${ }^{238} \mathrm{Pu}$-loaded $\mathrm{CWF}$ as an internal standard for instrument alignment purposes. Patterns were refined by the Rietveld method using General Structure Analysis System (GSAS) software [16] and quantitative phase analysis of the CWF was performed using the SIROQUANT software package [17].

The waste form is comprised of four crystalline phases and an amorphous phase as indicated by $\mathrm{x}$-ray diffraction. The phase composition of the ${ }^{238} \mathrm{Pu}$-loaded CWF in weight percent \pm uncertainty of the measurement is: sodalite, $66 \pm 7.9 ; \mathrm{PuO}_{2}, 4 \pm 1$; nepheline $\left(\mathrm{NaAlSiO}_{4}\right), 1 \pm$ 0.2 ; halite $(\mathrm{NaCl}), 1 \pm 0.2$, and the amorphous phase at $22 \pm 5.5 \mathrm{wt} \%$. The unit-cell composition of sodalite is $\mathrm{M}_{8} \mathrm{Al}_{6} \mathrm{Si}_{6} \mathrm{O}_{24} \mathrm{Cl}_{2}$, where $\mathrm{M}$ is $\mathrm{Li}$, $\mathrm{Na}$ or $\mathrm{K}$.

$\mathrm{X}$-ray diffraction patterns of the ${ }^{238} \mathrm{Pu}$-loaded sample have been acquired periodically for three years. From these analyses, changes to the phase composition and individual phase lattice parameters can be observed. The most notable change to date is the increase in the unit cell 
volume of the $\mathrm{PuO}_{2}$ phase and a slight increase in the volume of the sodalite phase. There is no indication of a change to the phase composition of the ${ }^{238} \mathrm{Pu}$-loaded sample. Figure 3 shows the $\mathrm{PuO}_{2}$ and sodalite unit-cell volume increase with increasing alpha-decay dose. In addition to the use of the $\mathrm{SRM} \mathrm{LaB}_{6}$ as an internal standard for sample alignment, the $\mathrm{LaB}_{6}$ was used to estimate the overall measurement uncertainty when calculating the unit-cell volume of each phase in the ${ }^{238} \mathrm{Pu}$-loaded sample. This measurement uncertainty is $\pm 0.025 \%$ relative standard deviation at the $1 \sigma$ confidence interval for both the $\mathrm{PuO}_{2}$ and sodalite phase as indicated in the figure.

The increase in the $\mathrm{PuO}_{2}$ unit-cell volume results from an accumulation of crystal lattice defects induced by alpha decay and has been described elsewhere [18]. The damage results from dissipation of energy from both the alpha particle and the recoil nucleus that emitted the alpha particle. Lattice defect damage to the $\mathrm{PuO}_{2}$ phase in the ${ }^{238} \mathrm{Pu}$-loaded CWF has also been observed by high resolution TEM [19]. The significance of the unit-cell volume increase of the $\mathrm{PuO}_{2}$ phase shown in Figure 3 is that the majority of the volume expansion (less than 1\%) occurred during the first 100 days with no observed deleterious effect to the physical or chemical durability of the waste form. The $\mathrm{PuO}_{2}$ phase unit-cell volume is expected to gradually increase with the in-growth of ${ }^{234} \mathrm{UO}_{2}\left({ }^{234} \mathrm{U}\right.$ has a larger ionic radius than $\left.{ }^{238} \mathrm{Pu}\right)$ in the solid solution. This expected volume increase is overlaid on the observed volume increase for the $\mathrm{PuO}_{2}$ phase in Figure 3. Indeed the radiation resilient behavior of the $\mathrm{PuO}_{2}$ (fluorite crystal structure) is well known and has been observed in other systems such as $\mathrm{UO}_{2}$ [20]. Figure 3 also shows an apparent sodalite lattice volume increase with accumulated alpha-decay damage, although, to a much less extent than the $\mathrm{PuO}_{2}$ phase $(0.2 \%$ and $0.7 \%$, respectively). The explanation for this volume increase is less obvious as very little $\mathrm{Pu}$ has been observed in the sodalite phase itself. While the $\mathrm{PuO}_{2}$ phase is observed to border the sodalite-glass boundaries, the limited range of the ${ }^{234} \mathrm{U}$ recoil nucleus in the $\mathrm{PuO}_{2}$ phase would preclude significant damage to the sodalite crystal structure. Microscopy analysis has identified a $\mathrm{Pu}$-silicate phase, but this phase appears to be discrete from the sodalite phase. A possible explanation for the sodalite unit-cell volume increase maybe the accumulation of defects from alpha-particle damage.

Figure 4 shows a comparison of the ${ }^{238} \mathrm{Pu}$-loaded CWF to other mineral systems that contain appreciable amounts of actinides for long periods of time. Figure 3 shows the swelling (percent volume increase) relative to cumulated alpha-decay dose for the $\mathrm{PuO}_{2}$ and sodalite phases in the CWF, several synthetic materials and natural 'analog' minerals containing actinides (zircon systems [21], Synroc-C [22], annealed $\mathrm{PuO}_{2}$ [23]). From this figure it is apparent that the

${ }^{238} \mathrm{Pu}$-loaded $\mathrm{CWF}$, at the current accumulated dose, experiences minimal swelling resulting from alpha decay damage and these observations are supported by the constant density of the CWF material with accumulated alpha-decay dose.

\section{SUMMARY}

The major observations from this interim report on the alpha-decay damage to the CWF after three years are as follows:

- No change in the microstructure or elemental composition of individual phases observed by SEM. TEM has observed bubbles or voids in the glass and sodalite phases and investigation is ongoing to determine their origin. No microcracks or phase debonding has been observed.

- The chemical durability of the ${ }^{238} \mathrm{Pu}$-loaded CWF has varied little from the initial testing period as determined by the PCT immersion test.

- The density of the ${ }^{238} \mathrm{Pu}$-loaded CWF has not changed within experimental uncertainty after nearly three years of measurement. 
- The phase composition of the ${ }^{238} \mathrm{Pu}$-loaded CWF as determined by XRD has not changed in nearly three years of observation. The $\mathrm{PuO}_{2}$ phase has undergone the expected maximum volume increase due to alpha-decay damage and continues to slowly increase in a manner consistent with the in-growth of ${ }^{234} \mathrm{U}$. The sodalite phase unit-cell volume also appears to be increasing, but to a much smaller extent than the $\mathrm{PuO}_{2}$ volume increase.

- The physical durability and appearance of the ${ }^{238} \mathrm{Pu}$-loaded CWF has remained unchanged af after nearly three years.

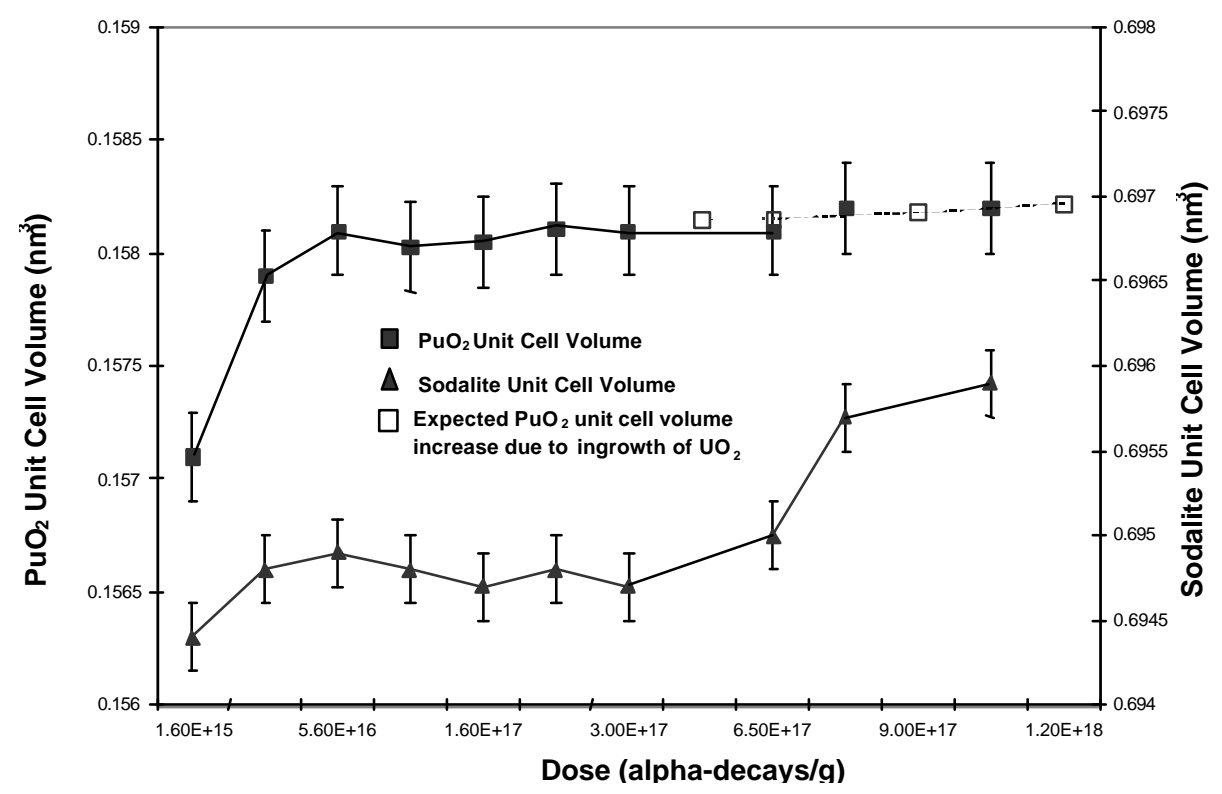

Figure 3. Unit cell volume increase of $\mathrm{PuO}_{2}$ and sodalite phase in ${ }^{238} \mathrm{Pu}$-loaded $\mathrm{CWF}$ with cumulated alpha-decay dose. The volume increase of the $\mathrm{PuO}_{2}$ phase is approximately $0.7 \%$ and $0.2 \%$ for the sodalite phase after a cumulated dose of $9.4 \times 10^{17}$ alpha-decays/gram of material.

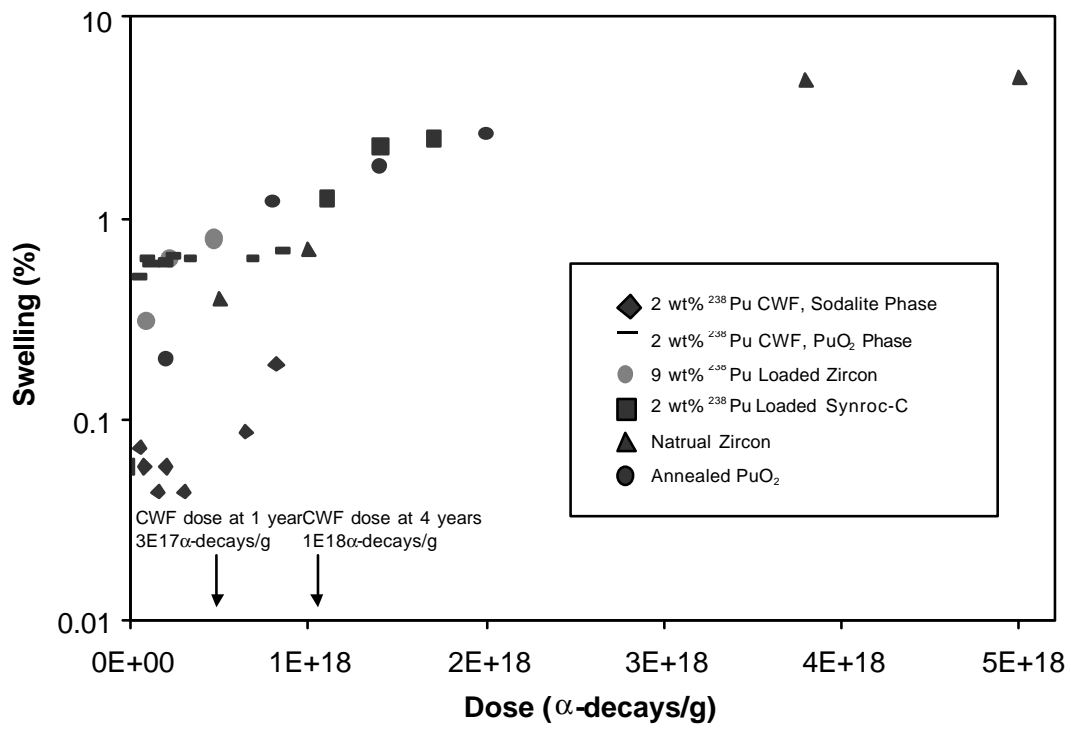

Figure 4. Swelling (percent volume increase) with cumulated alpha-decay dose for various mineral systems containing actinides including the $\mathrm{PuO}_{2}$ and sodalite phases from the ${ }^{238} \mathrm{Pu}-$ loaded CWF. 


\section{ACKNOWLEDGEMENTS}

This work was supported by the U.S. Department of Energy, Nuclear Energy Research and Development Program, under Contract No. W-31-109-ENG-38. Special thanks to D.G. Cummings and P.J. Crane for leachate analyses, R.N. Elliot, C.L. Brower and J. Colborn for hot cell sample preparation.

\section{REFERENCES}

1 K.M. Goff, R.W. Benedict, S.G. Johnson, R.D. Mariani, M.F. Simpson, B.R. Westphal, ANS Proceedings "Topical Meeting DOE Spent Nuclear Fuel and Fissile Materials Management", San Diego, CA, 58 (2000).

2 S.G. Johnson, K.M.Goff, W.L. Ebert, S. McDeavitt, WM01 Proceedings "HLW, LLW, Mixed, Hazardous Wastes and Environmental Restoration," Tucson, AZ, (2001).

3 R.C. Ewing, W.J. Weber, F.W. Clinard, Jr., Prog. Nucl. Energy 29 (2), 63 (1995).

4 S.M. Frank, S.G. Johnson, T.L. Moschetti, T.P. O’Holleran, W. Sinkler, K.M. Goff and D.W. Esh, Mat. Res. Soc. Symp. Proc., 608, 469-474 (2000).

5 S.M. Frank, D.W. Esh S.G. Johnson, M.H. Noy and T.P. O'Holleran, Mat. Res. Soc. Symp. Proc., 556, 1193-1198 (1999).

6 Y.Yokota, H.Hashimoto, and T.Yamaguchi, Ultramicroscopy, 54, 207-214 (1994).

7 B.G. Storey, T.R. Allen, Mat. Res. Soc. Symp. Proc., 481, 413-418 (1998).

8 S.X. Wang, L.M. Wang, and R.C. Ewing, J. Nucl. Mater., 278, 233-241 (2000).

9 D.G. Howitt, H.W. Chan, J.F. DeNatale, and J.P. Heuer, J. Am. Ceram. Soc., 74, 1145-1147 (1991).

10 E. Johnson, J.Ferrer, and L.T. Chadderton, Phys. Stat. Sol., (a)49, 585-591 (1996).

11 Y. Inagaki, H. Furuya, and K. Idemitsu, Mat. Res. Soc. Proc., 257, 199-206 (1992).

12 S. Sato, H. Furuya, T. Kozaka, Y. Inagaki, and T. Tamai, J. Nucl. Mat., 152, 265-269 (1989).

13 M.S. El-Genk, and J-M. Tournier, J. Nucl. Mat., 280, 1-17, (2000).

14 ASTM C1285-97, ASTM Philadelphia, PA, (1998).

15 L.W. Hobbs, F.W. Clinard, Jr., S.J. Zinkle, R.C. Ewing, J. Nucl. Mat., 216, 291-321 (1994).

16 Larson, A. C. and R. B. Von Dreele, GSAS, General Structure Analysis System, Los Alamos National Laboratory Report LAUR86-748 (1986).

17 SIROQUANT, version 2, Sietronics LTD., Belconnen, Australia.

18 R.P. Turcotte, T.D. Chikalla, Rad. Eff. 19, 99-108 (1973).

19 W. Sinkler, ANL-W, personal communication (2000).

20 W.J. Weber, J. Nucl. Mat., 98, 206-215 (1981).

21 W.J. Weber, J. Mater. Res., 5, 2687-2697 (1990).

22 K.A. Boult, J.T. Dalton, J.P. Evans, A.R. Hall, A.J. Inns. J.A.C. Marples, E.L. Paige, The preparation of fully active synroc and its radiation stability-Final Report, Oct. 1988. AERER-13318 (Harwell Laboratory, Harwell, UK, 1988).

23 T.D. Chikalla, R.P. Turcotte, Rad. Eff. 19, 93-98 (1973). 